\title{
Elucidating cylindrospermopsin toxicity via synthetic analogues: An in vitro approach
}

Daniel M. Evans ${ }^{1}$, Jack Hughes ${ }^{1}$, Leigh F. Jones ${ }^{1}$, Patrick J. Murphy ${ }^{1 *}$, Halina Falfushynska ${ }^{2}$, Oksana Horyn ${ }^{2}$, Inna M. Sokolova ${ }^{3}$, Jeppe Christensen ${ }^{4}$, Simon J. Coles ${ }^{4}$, Piotr Rzymski ${ }^{5}$

${ }^{1}$ School of Natural Sciences, Bangor University, Bangor, Gwynedd, LL57 2UW, United Kingdom

${ }^{2}$ Department of Human Health, Physical Rehabilitation and Vital Activity, Ternopil V. Hnatiuk National Pedagogical University, Ternopil, Ukraine

${ }^{3}$ Department of Marine Biology, Institute of Biological Sciences, University of Rostock, Rostock, Germany

${ }^{4}$ UK National Crystallographic Service, Chemistry, Faculty of Natural and Environmental Sciences, University of Southampton, England, SO17 1BJ, United Kingdom

${ }^{5}$ Department of Environmental Medicine, Poznan University of Medical Sciences, Poznań, Poland

* Corresponding author: Patrick J Murphy, School of Natural Sciences, Bangor University, Bangor, Gwynedd, LL57 2UW, United Kingdom, chs027@bangor.ac.uk

\footnotetext{
Abstract

Cylindrospermopsin (CYN) is an alkaloid biosynthesized by selected cyanobacteria, the cytoand genotoxic properties of which have been studied extensively by in vitro and in vivo experimental models. Various studies have separately established the role of uracil, guanidine and hydroxyl groups in CYN-induced toxicity. In the present study, we have prepared five synthetic analogues that all possess a uracil group but had variations in the other functionality found in CYN. We compared the in vitro toxicity of these analogues in common carp hepatocytes by assessing oxidative stress markers, DNA fragmentation and apoptosis. All the
} 
analogues tested induced generation of reactive oxygen species, lipid peroxidation (LPO) and DNA fragmentation. However, the greatest increase in LPO and increase in caspase-3 activity, an apoptosis marker, was demonstrated by an analogue containing guanidine, hydroxyl and uracil functionalities similar to those found in CYN but lacking the complex tricyclic structure of CYN. We also report a crystal structure of an analogue lacking the hydroxyl group found in CYN which does not show intramolecular H-bonding interactions between the guanidine and the uracil functionalities. The observations made in this work supports the hypothesis that CYN toxicity is a result of an interplay between both of the uracil, hydroxyl and guanidine functional groups.

Keywords: cylindrospermopsin; cyanobacteria; mechanism of action; hepatocytes; oxidative stress; DNA damage

\section{Introduction}

Cylindrospermopsin (CYN) $\mathbf{1}$ is a polyketide-derived alkaloid with a central functional guanidino-moiety combined with hydroxymethyluracil attached to its tricyclic carbon skeleton and is synthesized by a number of cyanobacterial species associated with the surface waters of Australia and New Zealand, Antarctica, Asia, South and North America and Europe (Rzymski and Poniedziałek 2014). Since CYN structure was first isolated from Raphidiopsis (formerly Cylindrospermopsis) raciborskii by Ohtani et al. (1992), it has been subject to extensive research on its potential ecological role (Rzymski et al. 2014; Dobronoki et al. 2018) and toxicity in eukaryotic organisms (Poniedziałek et al. 2012; Pichardo et al. 2017). Due to its in vivo metabolism, the toxin primarily targets liver and kidneys, but due to its generalized cytotoxicity it can also affect other organs (e.g., eye, spleen, lungs, thymus, heart). It can also impact the immune system cells and lead to alteration of different immune functions (Terao et 
al. 1994; Seawright et al. 1999; Poniedziałek et al. 2014a). As retrospectively suggested, CYN presence in the local water led to hospitalization of 148 people, the vast majority children, during the outbreak in 1979 (Byth 1980).

As shown, CYN displays a wide range of adverse cyto- and genotoxic effects encompassing generation of reactive oxygen species above the antioxidant cell capacity marked not only by consumption of catalase and superoxide dismutase but also by simultaneous inhibition of glutathione synthesis (Runnegar et al. 1995; Poniedziałek et al. 2015), irreversible protein synthesis inhibition (Terao et al. 1994), lipid peroxidation, genotoxicity manifested by DNA double-strand breaks and increased frequencies of micronucleus, nuclear buds and nucleoplasmic bridge formation (Straser et al. 2011), cell-cycle arrest and induction of necrosis and apoptosis (Lankof et al. 2007; Poniedziałek et al. 2014; Poniedziałek et al. 2015). It is plausible that these effects are all related, influence each other and result from CYN metabolism. However, genes encoding cytochrome P450 enzymes were shown to be upregulated following the CYN exposure, no direct evidence for phase I was found so far while phase II biotransformation was not studied (Kittler et al. 2016). Elucidating which structures of CYN are pivotal for its toxicity may be helpful in further understanding its metabolism and associated cellular effects.

Four structurally similar compounds to CYN 1 have also been isolated from cyanobacteria; 7-epi-cylindrospermopsin 2 (Banker et al. 2000), 7-deoxy-cylindrospermopsin 3 (Norris et al. 1999), 7-deoxy-desulfo-cylindrospermopsin $4 \quad$ and $\quad$ 7-deoxy-desulfo-12acetylcylindrospermopsin 5 (Wimmer et al. 2014), and research aimed to elucidate the potential role of various structural features of CYN 1 in its toxicity has been performed (Evans and Murphy 2011a). As already established, the exact stereochemistry of the hydroxyl group at C7 or the presence of the sulfate group had no significant effect in this regard, however the hydroxyl group appears to be essential for activity (Evans and Murphy 2011). It has similarly 
been postulated, that the uracil ring is pivotal in the expression of the biological activity of CYN 1 (Runnegar et al. 2002) (Figure 1(ii)). Our previous work in this area concentrated on the preparation of a series of simplified analogues 11a-c of CYN 1 in which the tricyclic moiety is missing and a pendant chain attaches the guanidinium portion of the molecule to the hydroxymethyluracil function. The tricyclic analogue $\mathbf{1 2}$ was also prepared which lacked the sulfate and hydroxyl functionality found in CYN 1 (Cartmell et al. 2017). We observed by comparison of bioactivity of the synthetic analogues that only those with a hydroxyl group at C-7 produced significant toxicity in human cells. The greatest toxicity was revealed by compound 11c, which possess a 6-carbon tether separating the guanidine and uracil groups. This tether length might allow the compound to adopt a similar conformation to that of CYN 1 as might a 4-carbon tether as compound 11a had similar activity. A tether length of 5-carbons (11b) revealed a significantly decreased bioactivity. These studies appear to highlight the profound role of the hydroxyl group at C-7 in uptake and toxicity and the lower activity of $\mathbf{1 1 b}$ might suggest that conformational effects in the analogues might also be a key factor (Cartmell et al. 2017) (Figure 1(ii)). This work gave a clear correlation between the presence of the guanidine, uracil and hydroxyl groups and the levels of activity (Cartmell et al. 2017). We wished to investigate the activity further and sought to prepare analogues in which each of these functional groups, with the exception of the uracil, was eliminated or modified. We thus sought to prepare the following analogues; compound 13, which lacks the hydroxyl and guanidine function, compound $\mathbf{1 4}$, which lacks the hydroxyl function only and compound $\mathbf{1 5}$, which lacks the guanidine function only. Where the guanine function is lacking, it was replaced with the amine functional group, as this should mimic the cationic nature of the guanidine (Figure 1(iii). In order to test the toxicity of these compounds, an in vitro experimental model using hepatocytes isolated from healthy Cyprinus carpio was employed. 

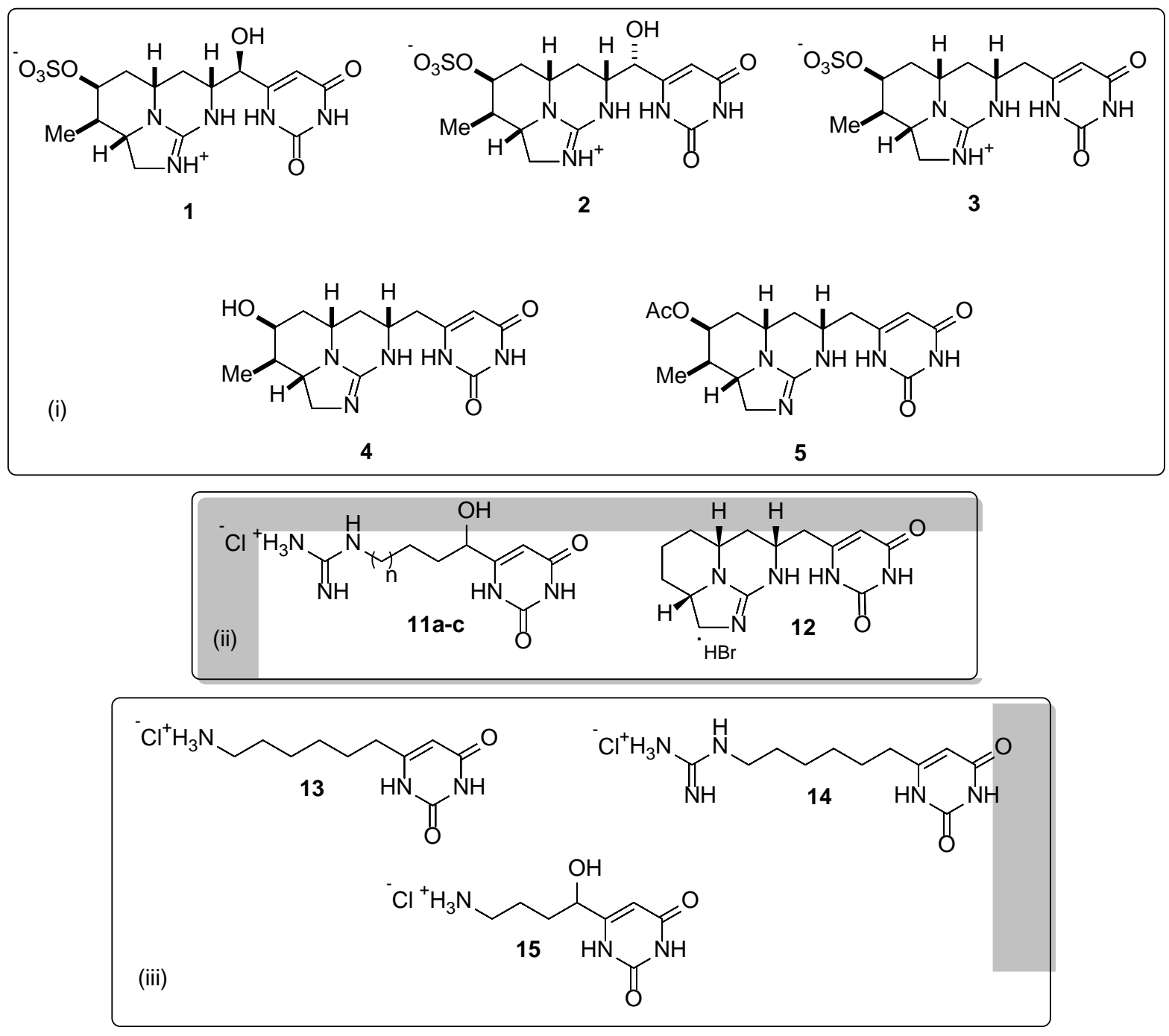

Figure 1. (i) The cylindrospermopsin alkaloids 1-5. (ii) The previously prepared analogues 11a-c ( $=1-3)$ and 12. (iii) New analogues 13-15 prepared in this study

\section{Materials and Methods}

\subsection{Synthesis}

Detailed information on starting materials, compound visualization and instruments employed in analogue synthesis are given in the Supplementary Material. 


\subsection{1. (E/Z)-6-(2,6-dimethoxypyrimidin-4-yl)hex-5-en-1-ol 18}

To a stirred suspension of phosphonium salt 17 (499.7 mg, $1.43 \mathrm{mmol})$ in anhydrous THF (20 mL) was added n-BuLi (1.14 mL, 2.86 mmol), after $1 \mathrm{~h}$ aldehyde 16 (240.4 mg, 1.43 mmol) in anhydrous THF (10 mL) was added drop-wise over 5 minutes. Reaction progress was monitored via TLC and after 2 h the reaction was quenched with $\mathrm{NH}_{4} \mathrm{Cl}$ (sat. $5 \mathrm{~mL}$ ), diluted with water $(5 \mathrm{~mL})$ and extracted with EA (3 x $25 \mathrm{~mL})$. The combined organic extracts where then dried over anhydrous $\mathrm{MgSO}_{4}$ and the solvent removed under reduced pressure. After evaporation, purification by flash column chromatography on silica gel using ethyl acetate in petroleum ether stepwise gradient of $25: 75$ to 50:50) gave 18 (0.29 g, $1.22 \mathrm{mmol}, 85 \%$, E/Z ratio 47:53) as a clear oil, which was used without further purification. $\mathbf{R}_{\boldsymbol{f}} 0.15$ (40\% ethyl acetate in petroleum ether); $\boldsymbol{v}_{\max } 3368,2935,2862,1644,1586,1556,1477,1458,1373,1354$, 1338, 1203; (E)-6-(2,6-dimethoxypyrimidin-4-yl)hex-5-en-1-ol $\boldsymbol{\delta}_{\mathbf{H}}$ 1.54-1.67 (4H, m, 2 х $\mathrm{CH}_{2}$ ), 2.26-2.31 (2H, m, $\left.\mathrm{CH}_{2}\right), 3.67$ (2H, t, J $\left.6.2 \mathrm{~Hz}, \mathrm{CH}_{2}\right), 3.95$ (3H, s, $\left.\mathrm{CH}_{3}\right), 4.00$ (3H, s, $\left.\mathrm{CH}_{3}\right)$, 6.18 (1H, s, CH), 6.29 (1H, d, J 15.2 Hz, CH), 7.01 (1H, dt, J 15.2, 7.2 Hz, CH); $\boldsymbol{\delta c} 25.6,29.0$, 32.3, 53.7, 54.7, 62.6, 98.3, 128.0, 139.7, 164.5, 165.2, 172.3; m/z (ESI) 499.3 (13\%, $\left.[2 \mathrm{M}+\mathrm{Na}]^{+}\right), 261.1\left(30 \%,[\mathrm{M}+\mathrm{Na}]^{+}\right), 239.1\left(100 \%,[\mathrm{M}+\mathrm{H}]^{+}\right)$; HRMS (ESI) found 239.1392 $\left([\mathrm{M}+\mathrm{H}]^{+}\right), \mathrm{C}_{12} \mathrm{H}_{19} \mathrm{O}_{3} \mathrm{~N}_{2}$ requires 239.1390. (Z)-6-(2,6-dimethoxypyrimidin-4-yl) hex-5-en-1ol $\boldsymbol{\delta}_{\mathbf{H}} 1.53-1.67$ (4H, m, 2 x CH$), 1.72$ (1H, br s, OH), 2.76-2.81 (2H, m, $\left.\mathrm{CH}_{2}\right), 3.66$ (2H, t, $J$ $6.1 \mathrm{~Hz}, \mathrm{CH}_{2}$ ), 3.95 (3H, s, $\mathrm{CH}_{3}$ ), 3.98 (3H, s, $\mathrm{CH}_{3}$ ), 5.98 (1H, dt, J 11.6, 7.6 Hz, CH), 6.19-6.22 (1H, m, CH), 6.22 (1H, s, CH); $3.96\left(3 \mathrm{H}, \mathrm{s}, \mathrm{CH}_{3}\right), 4.02\left(3 \mathrm{H}, \mathrm{s}, \mathrm{CH}_{3}\right), 4.06\left(3 \mathrm{H}, \mathrm{s}, \mathrm{CH}_{3}\right) 7.06$ (1H, s, CH); $\delta$ c 25.6, 29.0, 32.3, 53.7, 54.7, 62.7, 101.1, 126.6, 141.4, 165.2, 172.2 (1 x C not observed); $\mathbf{m} / \mathbf{z}(\mathrm{ESI}) 499.3\left(16 \%,[2 \mathrm{M}+\mathrm{Na}]^{+}\right), 261.1\left(35 \%,[\mathrm{M}+\mathrm{Na}]^{+}\right), 239.1\left(100 \%,[\mathrm{M}+\mathrm{H}]^{+}\right)$; HRMS (ESI) found $239.1392\left([\mathrm{M}+\mathrm{H}]^{+}\right), \mathrm{C}_{12} \mathrm{H}_{19} \mathrm{O}_{3} \mathrm{~N}_{2}$ requires 239.1390 . 


\subsubsection{6-(2,6-dimethoxypyrimidin-4-yl)hexan-1-ol 19}

Palladium on charcoal (10\%, $100 \mathrm{mg}$ ) was added to a solution of alkene $\mathbf{1 8}$ (979.6 mg, 4.11 mmol) in EA (20 mL) and the mixture stirred vigorously under a hydrogen atmosphere for 24 h. The reaction mixture was the filtered through a plug of celite ${ }^{\circledR}$ and the filter pad washed with ethyl acetate (3 x $50 \mathrm{~mL}$ ), the combined organic extracts where then dried over anhydrous $\mathrm{MgSO}_{4}$ and the solvent removed under reduced pressure. After evaporation, purification by flash column chromatography on silica gel using diethyl ether in petroleum ether (stepwise gradient of 40:60 to 60:40) gave 19 as a clear oil (587.2 mg, $2.44 \mathrm{mmol}, 59 \%$ ). $\mathbf{R}_{\boldsymbol{f}} 0.19$ (80\% diethyl ether in petroleum ether); $\boldsymbol{v}_{\max }$ 3368, 2988, 2934, 2860, 1595, 1567, 1482, 1459, 1385 , 1358, 1206; $\boldsymbol{\delta}_{\mathbf{H}} 1.32-1.43$ (4H, m, 2 x CH 2$), 1.49$ (1H, br s, OH), 1.53-1.60 (2H, m, $\mathrm{CH}_{2}$ ), 1.671.74 (2H, m, $\left.\mathrm{CH}_{2}\right), 2.59$ (2H, t, J 7.8 Hz, $\left.\mathrm{CH}_{2}\right), 3.64$ (2H, t, J 6.6 Hz, $\left.\mathrm{CH}_{2}\right), 3.94\left(3 \mathrm{H}, \mathrm{s}, \mathrm{CH}_{3}\right)$, 3.97 (3H, s, $\mathrm{CH}_{3}$ ), 6.19 (1H, s, CH); $\boldsymbol{\delta}$ c 25.4, 28.3, 28.9, 32.6, 37.3, 53.6, 54.5, 62.8, 99.5, 165.2, 171.8, 173.0; $\mathbf{m} / \mathbf{z}(\mathrm{ESI}) 503.3\left(18 \%,[2 \mathrm{M}+\mathrm{Na}]^{+}\right), 263.1\left(15 \%,[\mathrm{M}+\mathrm{Na}]^{+}\right), 241.2(100 \%$, $\left.[\mathrm{M}+\mathrm{H}]^{+}\right)$; HRMS (ESI) found $241.1547\left([\mathrm{M}+\mathrm{H}]^{+}\right), \mathrm{C}_{12} \mathrm{H}_{21} \mathrm{O}_{3} \mathrm{~N}_{2}$ requires 241.1547.

\subsubsection{6-(2,6-dimethoxypyrimidin-4-yl)hexan-1-amine 20}

To a cooled $\left(0{ }^{\circ} \mathrm{C}\right)$ and stirred solution of alcohol 19 (294.0 mg, $\left.1.22 \mathrm{mmol}\right)$, triphenylphosphine (673.8 mg, $2.57 \mathrm{mmol}$ ) and phthalimide (450.1 mg, $3.06 \mathrm{mmol})$ in anhydrous THF (10 mL) was added diisopropyl azodicarboxylate (DIAD, $0.51 \mathrm{~mL}, 2.57 \mathrm{mmol}$ ) and the mixture allowed to stir and warm to rt over $48 \mathrm{~h}$. The solvent was removed under reduced pressure and the residue dissolved in $\mathrm{EtOH}(15 \mathrm{~mL})$, ethylenediamine (0.82 mL, 12.23 mmol) was added and the mixture heated at reflux for $24 \mathrm{~h}$. The resulting precipitate was removed by filtration through a plug of celite ${ }^{\circledR}$ and the filter pad washed with EtOH $(3 \times 10$ $\mathrm{mL}$ ); the combined organic extracts where then dried over anhydrous $\mathrm{MgSO}_{4}$ and the solvent removed under reduced pressure. After evaporation, purification by flash column 
chromatography on silica gel (methanol in ethyl acetate stepwise gradient of 0:100 to 5:95 containing 1\% $\mathrm{NH}_{3}$ (aq. conc.)) gave 20 (242.9 mg, $1.02 \mathrm{mmol}$, 83\%) as a clear oil. $\mathbf{R}_{\boldsymbol{f}} 0.11$ (10\% methanol in ethyl acetate, $1 \% \mathrm{NH}_{3}$ (aq.)); $\boldsymbol{v}_{\max } 3400,2932,2859,1596,1566,1481,1459$, 1385, 1357, 1206; $\boldsymbol{\delta}_{\mathbf{H}} 1.33-1.40$ (4H, m, 2 х CH 2$), 1.44-1.52$ (2H, m, $\left.\mathrm{CH}_{2}\right), 1.64-1.73$ (2H, m, CH $\mathrm{CH}_{2}, 2.58$ (2H, t, J 7.6 Hz, CH ), 2.64 (2H, t, J 7.2 Hz, CH$), 3.95$ (3H, s, $\mathrm{CH}_{3}$ ), 3.97 (3H, s, $\mathrm{CH}_{3}$ ), 6.31 (1H, s, CH); $\boldsymbol{\delta c}$ 27.7, 29.7, 30.1, 33.6, 38.0, 42.5, 54.4, 55.1, 100.3, 166.7, 173.6, 174.7; $\mathbf{m} / \mathbf{z}(\mathrm{ESI}) 479.3\left(12 \%,[2 \mathrm{M}+\mathrm{H}]^{+}\right), 240.2\left(100 \%\right.$, $\left.[\mathrm{M}+\mathrm{H}]^{+}\right)$; HRMS (ESI) found 240.1706 $\left([\mathrm{M}+\mathrm{H}]^{+}\right), \mathrm{C}_{12} \mathrm{H}_{22} \mathrm{O}_{2} \mathrm{~N}_{3}$ requires 240.1707 .

\subsubsection{6-(6-aminohexyl)pyrimidine-2,4(1H,3H)-dione hydrochloride 13}

A solution of pyrimidine 20 (60.6 mg, $0.253 \mathrm{mmol})$ in $\mathrm{HCl}(2 \mathrm{M}, 3 \mathrm{~mL})$ was heated to $100{ }^{\circ} \mathrm{C}$. Reaction progress was monitored via TLC and after $36 \mathrm{~h}$ the reaction mixture was evaporated to dryness under reduced pressure and the residue obtained dried under vacuum over $\mathrm{P}_{2} \mathrm{O}_{5}$. After dissolving the residue in methanol (9 mL), containing 3 drops of $\mathrm{HCl}(12 \mathrm{M})$, diethyl ether (ca. $2 \mathrm{~mL}$ ) was added until the cloud point. After cooling $\left(-20^{\circ} \mathrm{C}\right)$ overnight, compound 13 (54.4 mg, 0.220 mmol, 87\%) was obtained as an off-white solid. M.p. $256{ }^{\circ} \mathrm{C}$ (decomp.); $\boldsymbol{v}_{\max } 2920,2852,2808,1708,1657,1600,1502,1463,1419,1356,1227 ; \boldsymbol{\delta}_{\mathbf{H}} 1.33-$ 1.42 (4H, m, 2 x CH 2$), 1.57-1.68$ (2H, m, 2 x CH 2$), 2.45$ (2H, t, J 7.6 Hz, CH2), 2.97 (2H, t, J 7.6 Hz, $\mathrm{CH}_{2}$ ), 5.63 (1H, s, CH); $\boldsymbol{\delta}$ c 25.2, 26.3, 26.5, 27.3, 31.9, 39.4, 98.7, 153.1, 159.5, 167.4; $\mathbf{m} / \mathbf{z}$ (ESI) $212.1\left(100 \%,[\mathrm{M}+\mathrm{H}]^{+}\right)$; HRMS (ESI) found $212.1394\left([\mathrm{M}+\mathrm{H}]^{+}\right), \mathrm{C}_{12} \mathrm{H}_{18} \mathrm{O}_{2} \mathrm{~N}_{3}$ requires 212.1394 .

\subsubsection{1-(6-(2,6-dioxo-1,2,3,6-tetrahydropyrimidin-4-yl)hexyl)guanidine hydrochloride 14}

1H-Pyrazole-1-carboxamidine hydrochloride $(61.1 \mathrm{mg}, 0.417 \mathrm{mmol})$ was added to a solution of the amine salt 13 (36.4 mg, $0.147 \mathrm{mmol}$ ) and $N, N$-diisopropylethylamine (DIPEA, 
$72.0 \mu \mathrm{L}, 0.42 \mathrm{mmol}$ ) in anhydrous DMF (5 mL) and the mixture stirred at $\mathrm{rt}$ for $48 \mathrm{~h}$. The dimethylformamide (DMF, $5 \mathrm{~mL}$ ) was removed by azeotropic evaporation with heptane (4 x $15 \mathrm{~mL}$ ) and the residue dried under high vacuum for $4 \mathrm{~h}$. The resulting material was then stirred with diethyl ether $(10 \mathrm{~mL})$ for $16 \mathrm{~h}$, the solvent decanted and the insoluble residue dissolved in water (5 mL) which was passed through a small plug of celite ${ }^{\circledR}$ (pipette) and the water evaporated under reduced pressure. Purification was achieved by slow crystallization from methanol/diethyl ether (2:3, $5 \mathrm{~mL})$ containing one drop of $\mathrm{HCl}(12 \mathrm{M})$, giving $14.2 \mathrm{H}_{2} \mathrm{O}(24.1$ mg, 0.074 mmol, 50 \%) as off-white crystals. M.p. 221-223 ${ }^{\circ} \mathrm{C}$; $\boldsymbol{v}_{\max } 3337,3174,2934,2856$, 1628, 1613, 1500, 1415, 1358, 1236; $\boldsymbol{\delta}_{\mathbf{H}} 1.37-1.46$ (4H, m, 2 х CH 2$), 1.55-1.71(4 \mathrm{H}, \mathrm{m}, 2$ х $\mathrm{CH}_{2}$ ), 2.41 (2H, t, J 7.6 Hz, $\mathrm{CH}_{2}$ ), 3.18 (2H, t, J 7.0 Hz, $\mathrm{CH}_{2}$ ), 5.46 (1H, s, CH); $\boldsymbol{\delta}$ c 27.3, 28.4, 29.7, 33.4, 42.4, 99.4, 153.6, 158.6, 159.3, 167.4; $\mathbf{m} / \mathbf{z}$ (ESI) $254.2\left(100 \%,[\mathrm{M}+\mathrm{H}]^{+}\right)$; HRMS (ESI) found $254.1613\left([\mathrm{M}+\mathrm{H}]^{+}\right), \mathrm{C}_{12} \mathrm{H}_{18} \mathrm{O}_{2} \mathrm{~N}_{3}$ requires 254.1612 .

\subsubsection{4-azido-1-(2,6-dimethoxypyrimidin-4-yl)butyl acetate 22}

A solution of the previously prepared alcohol 21 (Evans et al. 2014), 140.5 mg, 0.520 mmol), $\mathrm{PPh}_{3}$ (286.4 mg, $\left.1.092 \mathrm{mmol}\right)$ and DIAD (215 $\left.\mu \mathrm{L}, 1.092 \mathrm{mmol}\right)$ in anhydrous THF (10 $\mathrm{mL}$ ) was cooled to $-5{ }^{\circ} \mathrm{C}$ and stirred for 15 min. Diphenylphosphoryl azide (280 $\mu \mathrm{L}, 1.300$ mmol) was added and the mixture stirred to rt over $16 \mathrm{~h}$. After evaporation, purification by flash column chromatography on silica gel (diethyl ether in petroleum ether, stepwise gradient of 10:90 to 40:60) gave azide 22 (128.8 $\mathrm{mg}, 0.437 \mathrm{mmol}, 84 \%$ ) as a clear oil. $\mathbf{R}_{f} 0.33$ (60\% diethyl ether in petroleum ether; $\boldsymbol{v}_{\max } 2958,2105,1738,1594,1572,1483,1461,1386,1358,1241$, 1205; $\boldsymbol{\delta} \mathbf{H} 1.64-1.80$ (2H, m, CH 2$), 1.86-2.01$ (2H, m, $\left.\mathrm{CH}_{2}\right), 2.03$ (3H, s, $\left.\mathrm{CH}_{3}\right), 3.97$ (3H, s, $\left.\mathrm{CH}_{3}\right)$, 3.99 (3H, s, $\left.\mathrm{CH}_{3}\right), 4.08$ (2H, t, J $\left.6.0 \mathrm{~Hz}, \mathrm{CH}_{2}\right), 4.24(1 \mathrm{H}, \mathrm{dd}, J$ 6.0, $7.2 \mathrm{~Hz}, \mathrm{CH}), 6.37$ (1H, s, CH); $\boldsymbol{\delta c}$ 20.9, 25.0, 30.2, 54.0, 54.9, 63.7, 64.5, 98.7, 165.5, 169.1, 171.0, 172.4; m/z (ESI) 
$318.1\left(12 \%,[\mathrm{M}+\mathrm{Na}]^{+}\right), 296.1\left(100 \%,[\mathrm{M}+\mathrm{H}]^{+}\right)$; HRMS (ESI) found $296.1353\left([\mathrm{M}+\mathrm{H}]^{+}\right)$, $\mathrm{C}_{12} \mathrm{H}_{18} \mathrm{O}_{4} \mathrm{~N}_{5}$ requires 296.1353.

\subsubsection{6-(4-amino-1-hydroxybutyl)pyrimidine-2,4(1H,3H)-dione hydrochloride 15}

A solution of azide 22 (92.6 mg, $0.315 \mathrm{mmol})$ in $\mathrm{HCl}(2 \mathrm{M}, 19 \mathrm{~mL}$ ) was heated to 100 ${ }^{\circ} \mathrm{C}$. Progress of the reaction was monitored (TLC) and after $16 \mathrm{~h}$ the mixture was evaporated under reduced pressure and the residue dried under vacuum over $\mathrm{P}_{2} \mathrm{O}_{5}$. The residue was then dissolved in THF: $\mathrm{H}_{2} \mathrm{O}(4: 1,7 \mathrm{~mL})$ and cooled to $0{ }^{\circ} \mathrm{C} . \mathrm{PPh}_{3}(123.9 \mathrm{mg}, 0.475 \mathrm{mmol})$ was added and the mixture was stirred to rt over $48 \mathrm{~h}$. The reaction mixture was evaporated to dryness, triturated with water $(2 \times 2 \mathrm{~mL})$ and the triturates filtered through a thin pad of Celite $@$ (pipette) then evaporated under reduced pressure. The residue was dissolved in methanol $(5 \mathrm{~mL})$ containing 3 drops of $\mathrm{HCl}(12 \mathrm{M})$ and $\mathrm{DE}$ (ca. $2 \mathrm{~mL}$ ) was added until the cloud point. After cooling $\left(-20^{\circ} \mathrm{C}\right)$ overnight, 15 (27.1 $\mathrm{mg}, 0.115 \mathrm{mmol}$, $37 \%$ ) was obtained as an off-white solid. M.p. $228-230{ }^{\circ} \mathrm{C} ; \boldsymbol{v}_{\max } 3095,3033,2956,2883,2779,1681,1606,1495,1445,1398,1380$, 1326, 1286, 1258, 1244; $\boldsymbol{\delta}_{\mathbf{H}}$ 1.61-1.69 (2H, m, $\left.\mathrm{CH}_{2}\right), 2.02$ (2H, ddd, $J$ 2.4, 7.2, $10.0 \mathrm{~Hz}, \mathrm{CH}_{2}$ ), 3.64 (2H, td, J 5.9, $\left.1.8 \mathrm{~Hz}, \mathrm{CH}_{2}\right), 4.09$ (1H, t, $\left.J 7.2 \mathrm{~Hz}, \mathrm{CH}\right), 5.72(1 \mathrm{H}, \mathrm{s}, \mathrm{CH}) ; \boldsymbol{\delta} \mathbf{c} 28.9,31.0$, 52.6, 79.5, 99.4, 152.7, 153.7, 166.3; $\mathbf{m} / \mathbf{z}(\mathrm{ESI}) 797.4\left(6 \%,[4 \mathrm{M}+\mathrm{H}]^{+}\right), 620.3\left(12 \%,[3 \mathrm{M}+\mathrm{Na}]^{+}\right)$, $598.3\left(24 \%,[3 \mathrm{M}+\mathrm{H}]^{+}\right), 399.2\left(40 \%,[2 \mathrm{M}+\mathrm{H}]^{+}\right), 200.1\left(100 \%,[\mathrm{M}+\mathrm{H}]^{+}\right)$; HRMS (ESI) found $200.1027\left([\mathrm{M}+\mathrm{H}]^{+}\right), \mathrm{C}_{8} \mathrm{H}_{14} \mathrm{O}_{3} \mathrm{~N}_{3}$ requires 200.1030.

\subsection{Toxicological studies}

\subsubsection{Experimental design}

The toxicity of synthesized variants of CYN was compared in hepatocytes isolated from common carp Cyprinus carpio. This model has been chosen as previous studies have demonstrated that cyanobacterial compounds can target hepatocytes and that CYN can cause 
cell damage and oxidative stress specifically in fish hepatocytes (Gutiérrez-Praena et al. 2011; Falfushynska et al. 2019).

Hepatocytes were isolated by digestion in $100 \mu \mathrm{L}$ of $0.1 \%$ trypsin/EDTA for 2 min. The reaction was terminated by Dulbecco’s modified Eagle medium (1:3 v/v) supplemented with 20\% fetal calf serum (Burdon and van Knippenberg, 1991, Grunow et al., 2011). The viability of Percoll-purified cells was evaluated using trypan blue exclusion test. Hepatocytes yield was in the range of $50-80 \times 10^{6} \mathrm{~g}^{-1}$ liver and cell viability was higher than $82 \%$. Purified suspensions of the freshly isolated carp hepatocytes were resuspended in Hank's balanced salt solution without $\mathrm{Ca}^{2+}$ and $\mathrm{Mg}^{2+}$ at a density of $10^{7}$ cells $\mathrm{mL}^{-1}$. Cells were seeded in 24-well plates and allowed to attach. In each experiment cells ( $10^{7}$ cells per $\mathrm{mL}$ ) were exposed to $10 \mu \mathrm{g} \mathrm{mL}^{-1}$ of each analogue for $2 \mathrm{~h}$ at $20^{\circ} \mathrm{C}$. The control was constituted of cells unexposed to any analogue. At the end of the exposure, the isolated hepatocytes were washed in physiological saline, resuspended with trypsin and kept for further analysis. Selected parameters related to oxidative stress (lipid peroxidation, protein carbonyl, catalase activity), genotoxicity and apoptosis were tested. The results were standardized over the protein content determined in whole cell lysates using the Lowry protein assay (Lowry et al. 1951). Each assay was performed on 8 independent cell cultures of cells with each cell culture prepared from individual fish.

\subsubsection{Oxidative stress}

Immediately after exposure, hepatocytes pellet was re-suspended in 20 mM HEPES reached with $0.32 \mathrm{M}$ sucrose and centrifuged at $12000 \times \mathrm{g}$ for $45 \mathrm{~min}$ at $4^{\circ} \mathrm{C}$. The formation of reactive oxygen species (ROS) were determined in supernatant using dihydrorhodamine (Viarengo et al. 1974) with fluorescence measured by an f-max [Ex/Em $=485 / 538 \mathrm{~nm}]$ at 0 and after $20 \mathrm{~min}$. The rates of ROS generation were than calculated from these two values. 
Exposed hepatocytes were re-suspended in $50 \mathrm{mM}$ PBS $(1 / 10 \mathrm{w} / \mathrm{v})$ and centrifuged at $3000 \times \mathrm{g}$ for $5 \mathrm{~min}$ at $4^{\circ} \mathrm{C}$. Activity of catalase (CAT, EC 1.11.1.6) was evaluated in an aliquot of soluble fraction that contained approx. $150 \mu \mathrm{g}$ of proteins by the decomposition of $10 \mathrm{mM}$ $\mathrm{H}_{2} \mathrm{O}_{2}$ according to Aebi (1974) at $240 \mathrm{~nm}\left(\varepsilon=40 \mathrm{M}^{-1} \mathrm{~cm}^{-1}\right)$ in the $50 \mathrm{mM} \mathrm{KH}_{2} \mathrm{PO}_{4}(\mathrm{pH} 7.0)$ medium.

Lipid peroxidation (LPO) was evaluated by the production of TBA-reactive substances (TBARS) in a supernatant of isolated cell pellet. For that reason, isolated hepatocytes were resuspended in $50 \mathrm{mM}$ PBS $(1 / 10 \mathrm{w} / \mathrm{v})$ and proteins precipitated with $30 \%$ trichloroacetic acid (30\%). The absorbance of the final product was determined at $532 \mathrm{~nm}$. A molar extinction coefficient of $1.56 \cdot 105 \mathrm{M}^{-1} \mathrm{~cm}^{-1}$ was used. Results were expressed as pmol TBARS $\mathrm{mg}^{-1}$ protein.

Protein carbonyl (PC) concentration was evaluated in the pellet of the trichloroacetic acid-treated isolated cells by the reaction with 2,4-dinitrophenylhydrazine (DNPH) (Reznick and Packer 1994). Differences in the absorbance between the DNPH- and the HCl-treated samples were determined spectrophotometrically $(370 \mathrm{~nm})$, with the amount of carbonyls determined by using a molar extinction coefficient of $2.2 \cdot 104 \mathrm{M}^{-1} \mathrm{~cm}^{-1}$. Results were expressed as nmol PC $\mathrm{mg}^{-1}$ protein.

\subsubsection{DNA fragmentation}

Fragmentation of damage was evaluated in treated cells lysates in the mixture of $2 \%$ SDS, $10 \mathrm{mM}$ EDTA, $40 \mathrm{mM} \mathrm{NaOH}$ and $10 \mathrm{mM}$ Tris by the levels of protein-free DNA strand breaks by the alkaline DNA precipitation assay (Falfushynska et al. 2017) using Hoechst 33,342. The assay was performed in the presence of $0.4 \mathrm{M} \mathrm{NaCl}, 4 \mathrm{mM}$ sodium cholate, and 0.1 M Tris ( $\mathrm{pH}$ 9) to minimize the potential interference with traces of sodium dodecyl sulphate. The fluorescence was detected by an f-max $(\mathrm{Ex} / \mathrm{Em}=360 / 450 \mathrm{~nm})$. 


\subsubsection{Apoptosis}

Induction of apoptosis was evaluated by measuring the activity of caspase-3. The assay was based on the hydrolysis of peptide acetyl-Asp-Glu-Val-Asp p-nitroanilide (Ac-DEVDpNA) by caspase-3 that lead to formation of p-nitroaniline (Falfushynska et al. 2014). Briefly, treated hepatocytes were lysed by the addition of chilled cell lysis buffer containing $10 \mathrm{mM}$ HEPES, pH 7.4, 2 mM EDTA, 0.1\% CHAPS, 5 mM PMSF and 5 mM $\beta$-mercaptoethanol. Cell were incubated on ice for 10 minutes, homogenized and then centrifuged to remove the debris. Each sample was then incubated with Ac-DEVD-pNA for $1 \mathrm{~h}$ at $20^{\circ} \mathrm{C}$. The absorbance was measured at $405 \mathrm{~nm}$.

\subsubsection{Statistical analyses}

The statistical analyses were conducted using the Statistica 12.0 (StatSoft, United States). All data were normally distributed (tested with Levene test), and if Gaussian assumption was not met they were normalized by the Box-Cox transforming method. The effects of analogues on particular parameters were compared with one-way ANOVA with the Tukey HSD post-hoc test. $p<0.05$ was considered as statistically significant. Normally distributed data were subjected to the principal component analysis (PCA) to disclose the putative biomarker signatures of studied exposures.

\section{Results and Discussion}

\subsection{Synthesis}

The synthesis used a new methodology to access the three required analogs. Firstly the known aldehyde 16 (Cartmell et al. 2017) was reacted with the ylide prepared from the phosphonium salt 17 (Meyer and Collington 1971) to give the alkene 18 as a 47:53 mix of E:Z isomers in $85 \%$ yield (Figure 2). Hydrogenation over Pd/C was achieved in $59 \%$ yield to give 
19, which was converted to the amine 20 over two steps (Phthalimide/ $\mathrm{PPh}_{3} / \mathrm{DIAD}$ then ethylenediamine) in 83\% Yield. Finally, hydrolysis of the 2,4-dimethoxypyrimidine using hydrochloric acid (2 M) gave the required amine $\mathbf{1 3}$ as its hydrochloride salt in $87 \%$ yield. Guanidinylation of 13 using 1H-Pyrazole-1-carboxamidine hydrochloride gave the required guanidine 14 in 56\% after purification. Analogue 15 was prepared from the previously prepared alcohol 21 (Cartmell et al. 2017) using a similar strategy to that above. Alcohol 21 was firstly converted into the azide 22 using $\mathrm{PPh}_{3}$, DIAD and diphenylphosphoryl azide (DPPA) in 84\% yield. This was followed by hydrolysis of the 2,4-dimethoxypyrimidine and acetate groups in hydrochloric acid (2 M) and conversion of the azide functionality to the amine under Staudinger conditions to give $\mathbf{1 5}$ as a hydrochloride salt in 37\% yield over 2 steps (Figure 2).
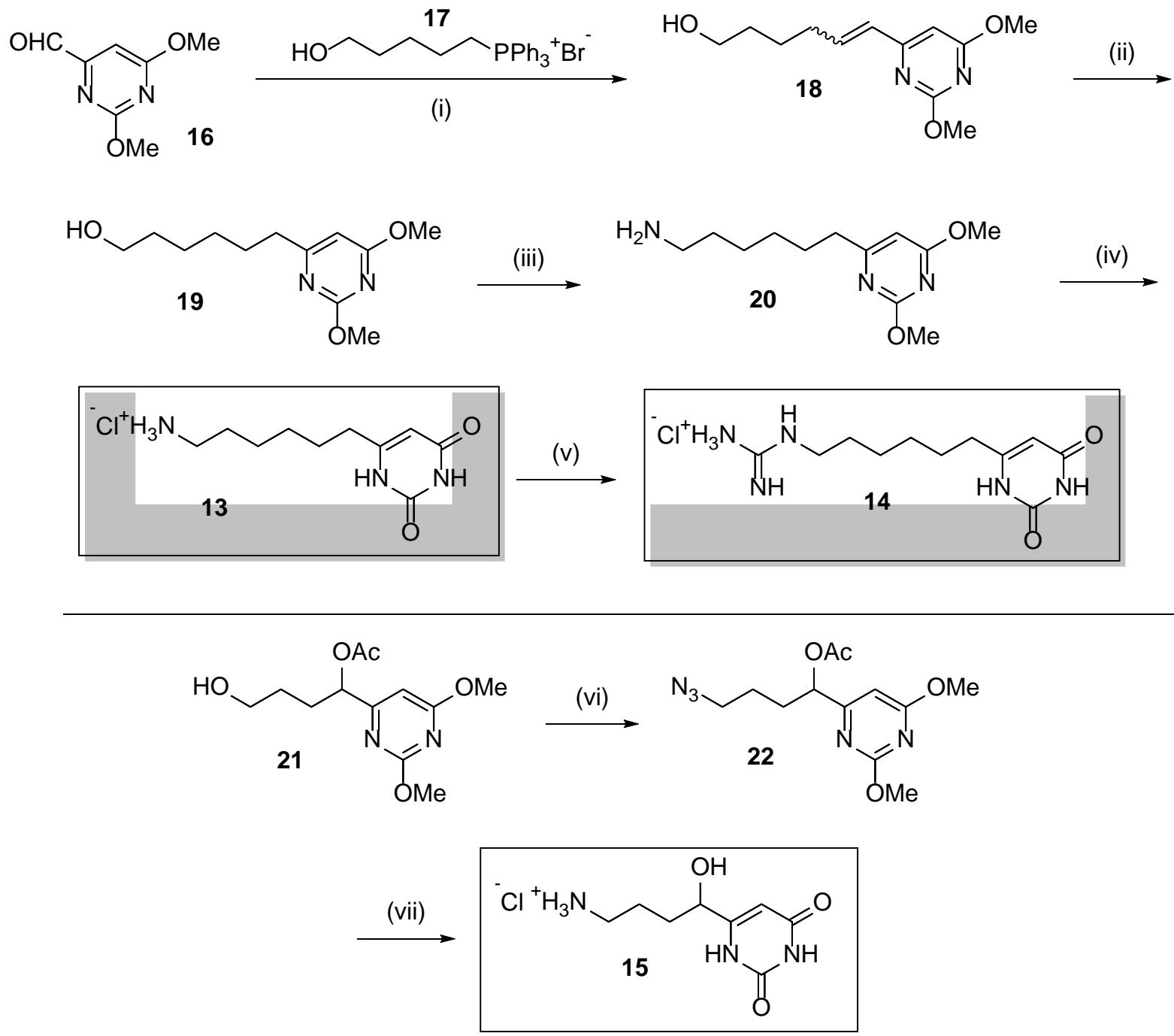
Figure 2. Synthesis of the analogues 13, 14 and 15: (i) (a) 17, $n$ BuLi, THF, 1 h. (b) 16, THF, 2 h, 85\%; (ii) H2, Pd/C, EA, 24 h, 59\%; (iii) (a) Phthalimide, PPh 3 , DIAD, THF, 48 h. (b) $\mathrm{H}_{2} \mathrm{~N}\left(\mathrm{CH}_{2}\right)_{2} \mathrm{NH}_{2}$, EtOH, 24 h, 83\% (over 2 steps); (iv) HCl (2 M), $100{ }^{\circ} \mathrm{C}, 36$ h, 87\%; (v) 1H-Pyrazole-1-carboxamidine hydrochloride, DIPEA, DMF, 48 h, 50\%; (vi) (a) $\mathrm{PPh}_{3}$, DIAD, THF, $-5{ }^{\circ} \mathrm{C}, 15$ min. (b) DPPA, $-5{ }^{\circ} \mathrm{C}$ - rt, 16 h, 84\%; (vii) (a) HCl (2 M), $100{ }^{\circ} \mathrm{C}$, 16h. (b). PPh, THF:H2O (4:1), $0{ }^{\circ} \mathrm{C}$ - rt, 48 h, $37 \%$ (over 2 steps).

\subsection{Toxicological activity}

Various studies have suggested that a given feature or features of the CYN 1 molecule, namely the uracil, the guanidinium ion or the hydroxyl group might be crucial for the toxicity of this cyanotoxin (Banker et al. 2001; Runnegar et al. 2002; Cartmell et al. 2017). As previously shown, compound 11a that contained all three motifs, displayed comparable toxicity to that of naturally occurring CYN 1, whilst the lack of the hydroxyl group in a more closely related structural analogue 12 significantly decreased the activity (Cartmell et al. 2017). As suggested, the hydroxyl group may increase CYN 1 reactivity due to the availability for hydrogen bond donors, or it may be involved in transport across the plasma membrane, e.g. via insertion of hydroxyl group into hydrophilic phospholipid head group, similarly to cholesterol (Cooper 2002). In the present work, the synthesis of specific CYN analogues allowed the comparison of guanidine and hydroxyl groups as potential active agents by employing an in vitro experimental model using hepatocytes isolated from Cyprinus carpio. This model was employed as previous studies have demonstrated that CYN can cause cell damage and oxidative stress in fish hepatocytes (Gutiérrez-Praena et al. 2011).

As found, all the CYN analogues tested (13-15, 11a and 11c) caused an increase in cellular ROS, lipid peroxidation and protein carbonylation, indicating an onset of oxidative stress (Figure 5). This indicates that all compounds can cross a cellular membrane, and despite previous assumptions, hydroxyl and guanidine groups may not be pivotal for this process, at 
least in hepatocytes. The greatest increase in lipid peroxidation and protein carbonylation was observed after exposure of hepatocytes to 11c and 11a, respectively. From the set of tested compounds, these two resemble naturally occurring CYN the most. Considering the differences in cellular response observed after treatment with the different analogues, it is possible to conclude that hydroxyl and guanidine groups have complimentary roles in the toxicity expressed by CYN. All compounds caused a similar increase in DNA fragmentation although only 11a and 11c induced an increase in caspase-3 activity, a marker of apoptosis that is known to be involved in CYN-mediated toxicity (Poniedziałek et al. 2014; López-Alonso et al. 2013; Poniedziałek et al. 2015).

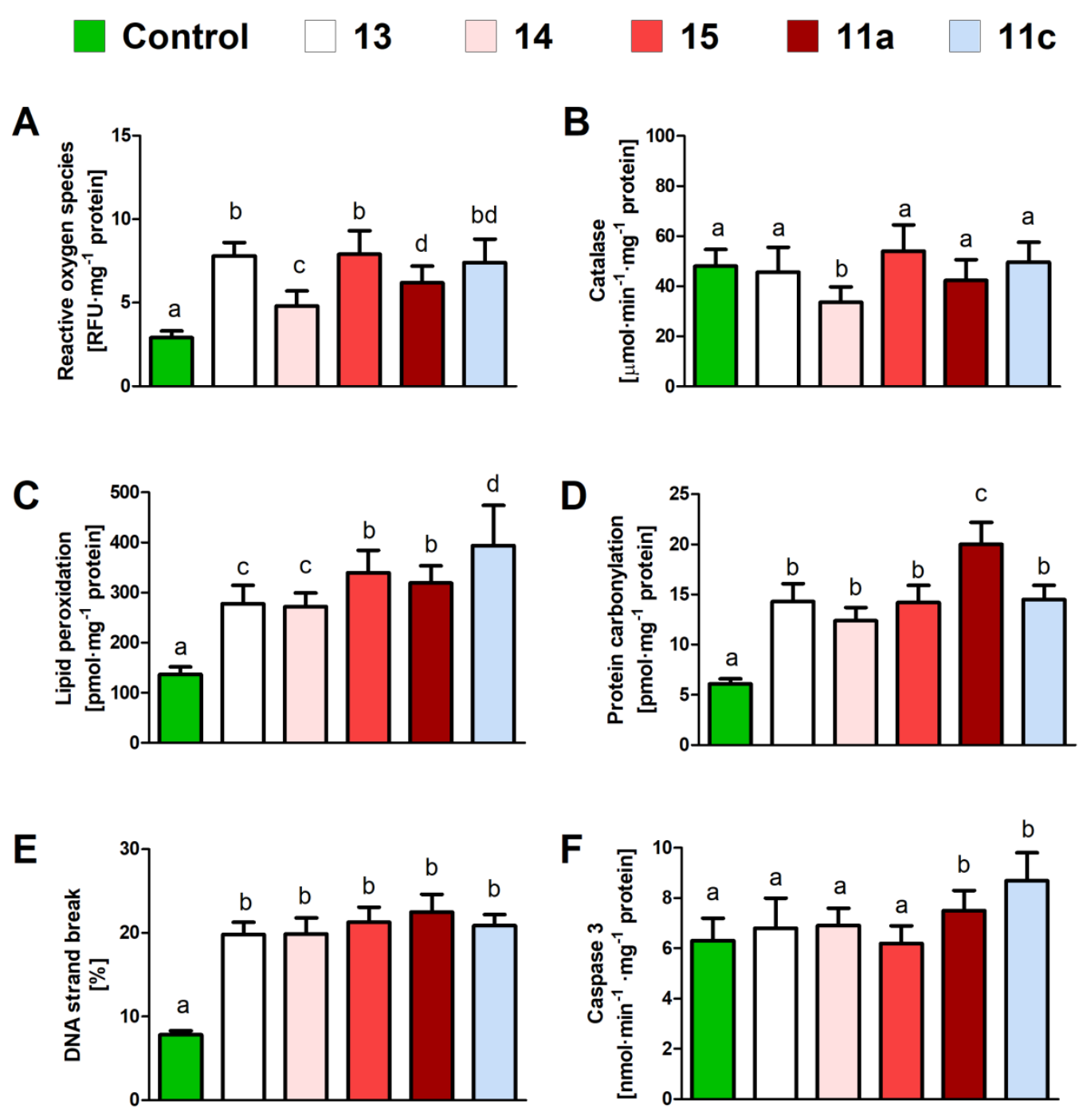


Figure 5. Generation of intracellular ROS (A), catalase activity (B), lipid peroxidation (C), protein carbonylation (D), DNA strand break (E) and caspase-3 activity (F) in fish hepatocytes $(n=8)$ after $2 \mathrm{~h}$ exposure to different CYN analogues (data presented as mean \pm SD). Different superscripts denote significant $(\mathrm{p}<0.05)$ differences between investigated analogues according to post-hoc Tukey's HDS test (ANOVA).

In general, analogue 14 (containing guanidine but lacking a hydroxyl group) caused the lowest increase in concentration of reactive oxygen species, and contrary to other compounds it did not increase CAT level. As revealed by Principal Cluster Analysis, the effects revealed by analogue 14) created a conjoin group with control along the PC2 axis, while all other effects induced by other analogues formed relatively tight clusters located on the opposite site (Figure 6). This is in line with previous findings by Cartmell et al. (2017) in which a synthetic analogue 12 and naturally occurring deoxy-CYN 3, both closely resembling CYN but lacking the hydroxyl group also displayed low activities. Similarly, the naturally occurring deoxy-CYN 3, has significantly lower toxicity again presumed due to lack of the hydroxyl-function.

Compound 15 (lacking guanidine) and 13 (lacking hydroxyl and guanidine) caused a similar response in various tests although $\mathbf{1 5}$ had a greater effect on increase in lipid peroxidation. This might indicate that the protonated amine is an effective surrogate for the protonated guanidine and the presence of a positively charged ion at this part of the molecule is a requirement for activity as has been observed in other synthetic analogues (Runnegar et al. 2002). The highest increase in this parameter was however, found after exposure to 11c (Figure 6). It thus appears that both the guanidine and hydroxyl groups have a role in CYN 1 toxicity, and the interplay of both these groups is responsible for the overall cellular effect of this cyanotoxin. The presence of an allylic hydroxyl group may offer the possibility for the 
formation of hydroxyl radicals, a process that is involved in lipid peroxidation via hydrogen radical abstraction followed by $\mathrm{O}_{2}$ addition (Tejero et al. 2007).

One should note that this applied the same mass concentration of each analogue and due to the difference in their molecular weight, the molar concentrations to which cells were exposed slightly vary. However, the hypothesis that increased number of molecules may increase the toxic effects is not justified as analogue 11c with the lowest molecular weight revealed to be most potent in some assays.

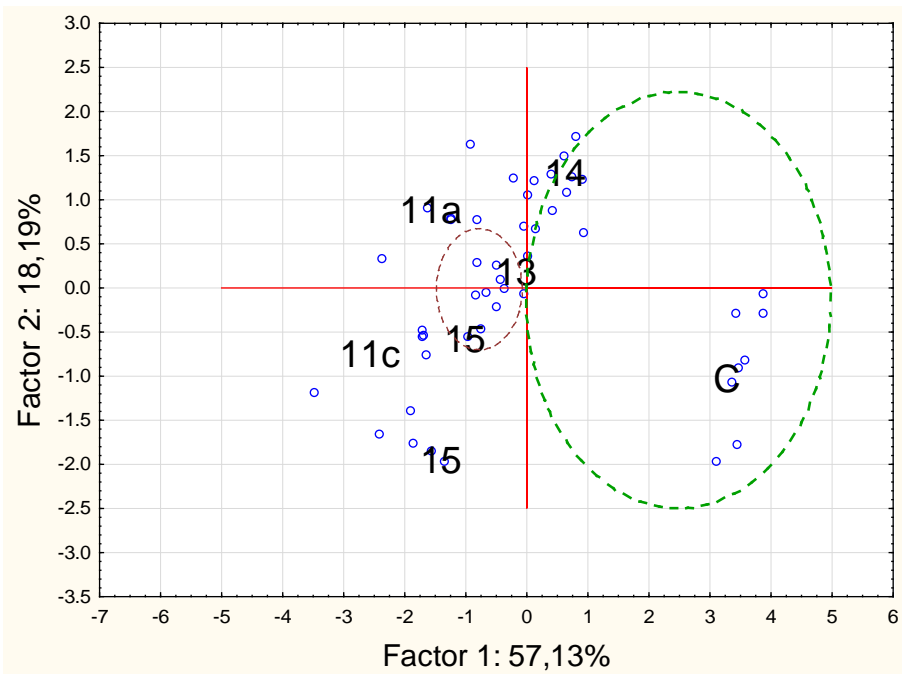

Figure 6. Principal component analysis for all studied biological traits in fish hepatocytes after 2 h exposure to different CYN 1 analogues (13-15, 11a, 11c) and control (C).

It is possible that guanidine related $\mathrm{NH}$ group(s), the hydroxyl and the uracil, which are proximal in the molecules studied, might interact via intramolecular hydrogen bonding and these functional groups have the ability to form specific interactions with their biomolecular targets. Potentially this may favour a decrease in polarity from the environment, making molecules more lipophilic and increasing their membrane permeability (Kuhn et al. 2010), thus resulting in higher cytotoxicity and greater oxidative stress. With these thoughts in mind we decided to obtain the crystal structure of 1-(6-(2,6-dioxo-1,2,3,6-tetrahydropyrimidin-4-

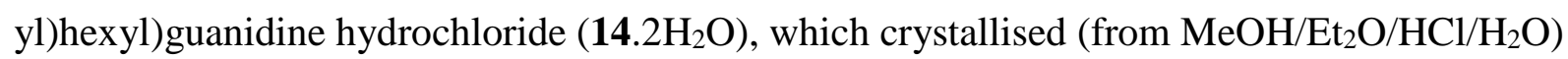
in the Triclinic P-1 space group (see Table S1 for details). The asymmetric unit in $\mathbf{1 4}$ comprises 
one complete organic moiety, a single chloride counter anion and two waters of crystallisation. Upon close inspection of this structure, it is apparent that there are no intramolecular interactions of note in the solid state, presumably due (at least in part) to the absence of an $\mathrm{OH}$ group whose position in, for instance 11a-c and 15, might allow for the formation of H-bonded six membered rings when displaying a closed conformation. This inability to forge such intramolecular interactions may have significant ramifications with respect to lipophilicity and membrane permeability as indicated by the weaker CAT activity and general response in $\mathbf{1 4}$. Although intramolecular exchanges are not observed in the crystal structure of $\mathbf{1 4}$,

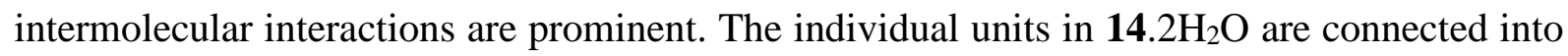
$1 \mathrm{D}$ rows through multiple interactions involving the $\mathrm{Cl}^{-}$counter anions at the guanidine end of the moiety $\left(\mathrm{N} 1(\mathrm{HN} 1 \mathrm{~B}){ }^{\cdots} \mathrm{Cl}^{\prime}=2.81 \AA\right.$ and $\left.\mathrm{N} 2(\mathrm{HN} 2 \mathrm{~A})^{\cdots} \mathrm{Cl}^{\prime}=2.39 \AA\right)$ and self-

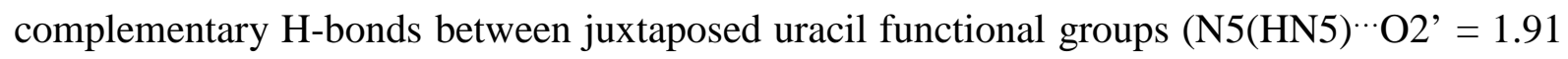
$\AA$ (and s.e.)) at the other extremity (Figure 7). The chloride counter anions and waters of crystallisation partake in H-bonding with each other $\left(\mathrm{O} 3(\mathrm{HO} \mathrm{A}){ }^{\cdots} \mathrm{O} 4=1.87 \AA\right.$; $\mathrm{O} 4(\mathrm{HO} 4 \mathrm{~B}) \cdots \mathrm{Cl} 1=2.29 \AA)$ as well as with the organic units in $14.2 \mathrm{H}_{2} \mathrm{O}$ at distances of $(\AA)$ : $2.32(\mathrm{~N} 4(\mathrm{HN} 4) \cdots \mathrm{Cl}), 2.03(\mathrm{~N} 3(\mathrm{HN} 3) \cdots \mathrm{O} 3)$ and $2.10(\mathrm{~N} 2(\mathrm{HN} 2 \mathrm{~B}) \cdots \mathrm{O} 4)$, resulting in a $2 \mathrm{D} \mathrm{H}-$ bonded sheet formation. These counter anions and unbound water molecules also sit in-between

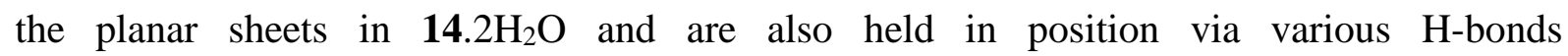
$\left(\mathrm{O} 3(\mathrm{HO} 3 \mathrm{~A}){ }^{\cdots} \mathrm{Cl} 1^{\prime}=2.40 \AA \AA\right)$ and long contacts $\left(\mathrm{C} 1(\mathrm{H} 2 \mathrm{~A}){ }^{\cdots} \mathrm{Cl} 1^{\prime}=2.81 \AA\right.$ ) with each other as well as with neighboring organic units. 

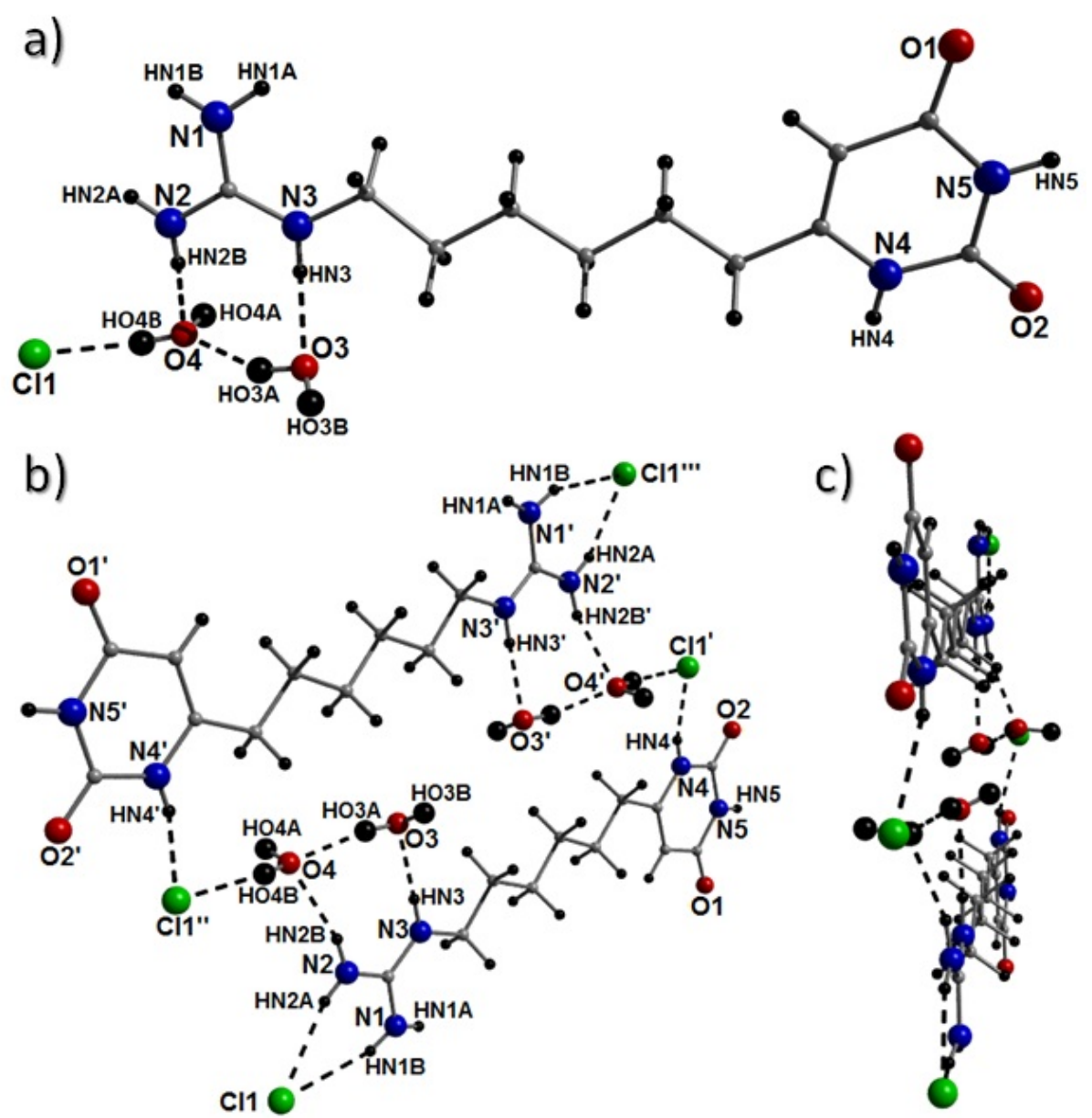

Figure 7. (a) The asymmetric unit in $\mathbf{1 4} 2 \mathrm{H}_{2} \mathrm{O}$. Dashed lines represent intermolecular $\mathrm{H}$ bonding at distances ( $\AA$ ): $2.10(\mathrm{~N} 2(\mathrm{HN} 2 \mathrm{~B}) \cdots \mathrm{O} 4) ; 2.29\left(\mathrm{O} 4(\mathrm{HO} 4 \mathrm{~B}){ }^{\cdots} \mathrm{Cl} 1\right)$ and 2.03 (N3(HN3) $\cdots$ O3). (b) Two units of $\mathbf{1 4} 2 \mathrm{H}_{2} \mathrm{O}$ interconnected along a 2D plane through numerous H-bonding interactions (as shown in (a)). (c) Side-view of the arrangement given in (b) highlighting the 2D H-bonded sheet-like array in $\mathbf{1 4} \cdot 2 \mathrm{H}_{2} \mathrm{O}$.

Altogether, these and previous findings suggest that all three, guanidine, uracil and hydroxyl groups are pivotal for CYN-induced toxicity in eukaryotic cells, including hepatocytes (Banker et al. 2001; Runnegar et al. 2002; Cartmell et al. 2017). This effect may be due to metabolites generated under CYN 1 metabolism, however, the exact process underlying the metabolic activation is still poorly understood. It has been speculated that the CYP1A subfamily of enzymes may be involved (Straser et al. 2011; Hercog et al. 2017; Puerto 
et al. 2018), and as demonstrated by Humpage et al. (2005), cytotoxicity of CYN can be associated with CYP450-derived metabolites. As shown by Kittler et al. (2016) in HepaRG line, inhibition of CYP3A4 has led to decrease in CYN cytotoxicity but no metabolites were detected providing no evidence for phase I biotransformation. Further studies on phase II metabolism which can generate reactive and instable metabolites are required to fully assess the intracellular steps of CYN-induced toxicity.

\section{Conclusions}

The present study is a continuation exploring a biological activity of synthetic analogues of CYN prepared in order to elucidate the structures involved in toxicity of naturally occurring compound. As indicated using experimental in vitro studies employing fish hepatocytes, whilst both guanidine and hydroxyl groups are key to CYN 1 toxicity, it is an interplay between these two that appears to magnify the observed cellular damage such as inducement of lipid peroxidation and apoptosis.

\section{Acknowledgments}

This research was partially funded by the Ministry of Education and Science of Ukraine (program for support young fellows MV-1) and by the BEACON (ERDF) program and the EPSRC. Thanks are given to the EPSRC for a fellowship (DE, EP/J01821X/1), the BEACON (ERDF) program for support (PJM, DE) and to the National Mass Spectrometry Facility at Swansea.

\section{Conflict of interest}

None to declare 


\section{References}

1. Aebi, H. Catalase. Method. Enzym. Anal. 1974, 2, 673-677.

2. Banker, R; Carmeli, S; Teltsch, B; Sukenik, A. 7-epicylindrospermopsin, a toxic minor metabolite of the cyanobacterium Aphanizomenon ovalisporum from Lake Kinneret, Israel. J Nat Prod 2000, 63, 387-389

3. Banker, R; Carmeli, S; Werman, M; Teltsch, B; Porat, R; Sukenik, A. Uracil moiety is required for toxicity of the cyanobacterial hepatotoxin cylindrospermopsin. $J$ Toxicol Environ Health: Part A 2001, 62, 281-288.

4. Byth, S. Palm Island mystery disease. Med. J. Aust. 1980, 2, 40-42.

5. Cartmell, C.; Evans, D.M.; Elwood, J.M.L.; Fituri, H.S.; Murphy, P.J.; Caspari, T.; Poniedzialek, B.; Rzymski, P. Synthetic analogues of cyanobacterial alkaloid cylindrospermopsin and their toxicological activity. Toxicol. In Vitro 2017, 44, 172-181.

6. Cooper, G.M. The Cell, 2nd Edition. Sinauer Associates, Sunderland, USA, 2002.

7. Dobronoki, D.; B-Béres, V.; Vasas, G.; Gonda, S.; Nagy, S.A.; Basci, I. 2018. Potential role of the cellular matrix of Aphanizomenon strains in the effects of cylindrospermopsin - an experimental study. J. Appl. Phycol. DOI: 10.1007/s10811-018-1699-4

8. Evans, D.M.; Horton, P.N.; Hursthouse, M.B.; Murphy, P.J. Preparation of an ABC tricyclic model of the cylindrospermopsin alkaloids via a biomimetically inspired pathway. RSC Adv. 2014, 4, 20744-20751.

9. Evans, D.M.; Murphy, P.J. A biomimetic approach to the cylindrospermopsin alkaloids, Chem. Commun. 2011, 44, 3225-3226.

10. Evans, D.M.; Murphy, P.J. The Alkaloids: Chemistry and Biology, 1st ed.; Academic Press: London, UK, 2011; pp. 1-77.

11. Falfushynska, H.; Gnatyshyna, L.; Turta, O.; Stoliar, O.; Mitina, N.; Zaichenko, A.; Stoika, R. Responses of hepatic metallothioneins and apoptotic activity in Carassius auratus 
gibelio witness a release of cobalt and zinc from waterborne nanoscale composites. Comp. Biochem. Physiol. 2014, 160, 66-74.

12. Falfushynska, H.; Horyn, O.; Brzozowska, A.; Fedoruk, O.; Buyak, B.; Poznansky, D.; Poniedziałek, B.; Kokociński, M.; Rzymski P. Is the presence of Central European strains of Raphidiopsis (Cylindrospermopsis) raciborskii a threat to a freshwater fish? An in vitro toxicological study in common carp cells. Aquat. Toxicol. 2019, 206, 105-113.

13. Falfushynska, H.I.; Gnatyshyna, L.L.; Horyn, O.; Stoliar, O.B. Vulnerability of marsh frog Pelophylax ridibundus to the typical wastewater effluents ibuprofen, triclosan and estrone, detected by multi-biomarker approach. Comp. Biochem. Physiol. 2017; 202, 26-38.

14. Gutiérrez-Praena, D.; Pichardo, S.; Jos, A.; Cameán, A.M. Toxicity and glutathione implication in the effects observed by exposure of the liver fish cell line PLHC-1 to pure cylindrospermopsin. Ecotoxicol. Environ. Saf. 2011, 74, 1567-1572.

15. Hercog, K.; Maisanaba, S.; Filipic, M.; Jos, A.; Cameánn, A.M.; Zegura, B. Genotoxic potential of the binary mixture of cyanotoxins microcystin-LR and cylindrospermopsin. Chemosphere 2017, 189, 319-329.

16. Humpage, A.R.; Fontaine, F.; Froscio, S.; Burcham, P.; Falconer, I.R. Cylindrospermopsin genotoxicity and cytotoxicity: Role of cytochrome P-450 and oxidative stress. J. Toxicol. Environ. Health Part A 2005, 68, 739-753.

17. Kittler, K.; Hurtaud-Pessel, D.; Maul, R.; Kolrep, F.; Fessard, V. In vitro metabolism of the cyanotoxin cylindrospermopsin in HepaRGcells and liver tissue fractions. Toxicon 2016, 110, 47-50.

18. Kuhn B.; Mohr P.; Stahl M. Intramolecular Hydrogen Bonding in Medicinal Chemistry. J. Med. Chem. 2010, 53, 2601-2611 
19. Lankoff, A.; Wojcik, A.; Lisowska, H.; Bialczyk, J.; Dziga, D.; Carmichael, W.W. No induction of structural chromosomal aberrations in cylindrospermopsin-treated CHO-K1 cells without and with metabolic activation. Toxicon 2007; 50, 1105-1115.

20. Lei, H.; Atkinson, J. Synthesis of phytyl- and chroman-derivatized photoaffinity labels based on $\alpha$-tocopherol J. Org. Chem., 2000, 65, 2560-2567.

21. López-Alonso, H.; Rubiolo, J.A.; Vega, F.; Vieytes, M.R.; Botana, L.M. Protein synthesis inhibition and oxidative stress induced by cylindrospermopsin elicit apoptosis in primary rat hepatocytes. Chem. Res. Toxicol. 2013, 26, 203-212.

22. Lowry, O.H.; Rosebrough, N.J.; Farr, A.L.; Randall, R.J. Protein measurement with the Folin phenol reagent. Biol. Chem. 1951, 193, 265275.

23. Meyers, A.I.; Collington, E.W. An efficient total synthesis of propylure, the highly active sex attractant for the pink bollworm moth. Tetrahedron, 1971, 27, 5979-5985.

24. Norris, RL; Eaglesham, G; Pierens, G; Shaw, G; Smith, MJ; Chiswell, RK; Seawright, AA; Moore, MR. Deoxycylindrospermopsin, an analog of cylindrospermopsin from Cylindrospermopsis raciborskii. Environ. Toxicol. 1999, 14, 163-165.

25. Ohkawa, H.; Onishi, N.; Yagi, K. Assay for lipid peroxidation in animal tissue by thiobarbituric acid reaction. Anal. Biochem. 1979, 95, 351-358.

26. Ohtani, I.; Moore, R.E.; Runnegar, M.T.C. Cylindrospermopsin: A potent hepatotoxin from the bluegreen alga Cylindrospermopsis raciborskii. J. Am. Chem. Soc. 1992, 114, 7941-7942.

27. Pichardo S, Cameán AM, Jos A. In vitro toxicological assessment of cylindrospermopsin: A review. Toxins 2017; 9.

28. Poniedzialek, B.; Rzymski, P.; Karczewski, J. Cylindrospermopsin decreases the oxidative burst capacity of human neutrophils. Toxicon 2014, 87, 113-119. 
29. Poniedzialek, B.; Rzymski, P.; Karczewski, J. The role of the enzymatic antioxidant system in cylindrospermopsin-induced toxicity in human lymphocytes. Toxicol. In Vitro 2015, 29, 926-932.

30. Poniedziałek, B.; Rzymski, P.; Kokociński, M. Cylindrospermopsin: Water-linked potential threat to human health in Europe. Environ. Toxicol. Pharmacol. 2012, 34, 651660.

31. Poniedzialek, B.; Rzymski, P.; Kokocinski, M.; Karcewski, J. Toxic potencies of metabolite(s) of non-cylindrospermopsin producing Cylindrospermopsis raciborskii isolated from temperate zone in human white cells. Chemosphere 2015, 120, 608-614.

32. Poniedzialek, B.; Rzymski, P.; Wiktorowicz, K. Toxocity of cylindrospermopsin in human lymphocytes: Proliferation, viability and cell cycle studies. Toxicol. In Vitro 2014, 28, 968974.

33. Puerto, M.; Prieto, A.I.; Maisanaba, S.; Gutiérrez-Praena, D.; Mellado-García, P.; Jos, Á.; Cameán, A.M. Mutagenic and genotoxic potential of pure Cylindrospermopsin by a battery of in vitro tests. Food Chem. Toxicol. 2018, 121, 413-422.

34. Reznick, A.Z.; Packer, L. Oxidative damage to proteins: spectrophotometric method for carbonyl assay. Meth. Enzymol. 1994, 233, 357-363.

35. Runnegar, MT; Xie, C; Snider, BB; Wallace, GA; Weinreb, SM; Kuhlenkamp, J. In vitro hepatotoxicity of the cyanobacterial alkaloid cylindrospermopsin and related synthetic analogues. Toxicol. Sci. 2002, 67, 81-87.

36. Rzymski, P.; Poniedziałek, B. In search of environmental role of cylindrospermopsin: A review on global distribution and ecology of its producers. Water Res. 2014, 66, 320-337.

37. Rzymski, P.; Poniedziałek, B.; Kokociński, M.; Jurczak, T.; Lipski, D.; Wiktorowicz, K. Interspecific allelopathy in cyanobacteria: Cylindrospermopsin and Cylindrospermopsis 
raciborskii effect on the growth and metabolism of Microcystis aeruginosa. Harmful Algae 2014, 35, 1-8.

38. Seawright, A.A.; Nolan, C.C.; Shaw, G.R.; Chiswell, R.K.; Norris, R.L.; Moore, M.R.; Smith, M.J. The oral toxicity for mice of the tropical cyanobacterium Cylindrospermopsin raciborskii (Woloszynska). Environ. Toxicol. 1999, 14, 135-142.

39. Straser, A.; Filipic, M.; Zegura, B. Genotoxic effects of the cyanobacterial hepatotoxin cylindrospermopsin in the HepG2 cell line. Arch. Toxicol. 2011, 85, 1617-1626.

40. Tejero, I.; Gonzalez-Lafont, A.; Lluch, J.M.; Eriksson, L.A. Theoretical modeling of hydroxyl-radical-induced lipid peroxidation reactions. J. Phys. Chem. B 2007, 111, 56845693

41. Terao, K.; Ohmori, S.; Igarashi, K.; Ohtani, I.; Watanabe, M.F.; Harada, K.I.; Ito, E.; Watanabe, M. Electron-microscopic studies on experimental poisoning in mice induced by cylindrospermopsin isolated from blue-green-alga Umezakia natans. Toxicon 1994, 32, 833-843.

42. Viarengo, A.; Burlando, B.; Cavaletto, M.; Marchi, B.; Ponzano, E.; Blasco, J. Role of metallothionein against oxidative stress in the mussel Mytilus galloprovincialis. Am. J. Physiol. 1999, 277,1612-1619.

43. Wimmer, K.M.; Strangman, W.K.; Wright, J.L.C. 7-Deoxy-desulfo-cylindrospermopsin and 7-deoxy-desulfo-12-acetylcylindrospermopsin: Two new cylindrospermopsin analogs isolated from a Thai strain of Cylindrospermopsis raciborskii. Harmful Algae 2014, 37, 203-206. 